\title{
TREATMENT ADHERENCE: THE EXPERIENCE OF ADOLESCENTS WITH HIV/AIDS
}

\author{
Maria Fernanda Cabral Kourrouski ${ }^{1}$ \\ Regina Aparecida Garcia de Lima ${ }^{2}$
}

Kourrouski MFC, Lima RAG. Treatment adherence: the experience of adolescents with HIV/Aids. Rev Latino-am Enfermagem 2009 novembro-dezembro; 17(6):947-52.

Living with a chronic condition is difficult at any stage of life, especially when considering HIV/AIDS, a stigmatized condition that elicits so much discrimination and which may become an aggravating factor when it occurs during adolescence. This study aimed to understand the experience of adolescents with HIV/AIDS concerning medication adherence. This is a descriptive study with a qualitative approach. Nine adolescents aged between 12 and 18 years and six caregivers participated in the study. The organization of data focused on positive and negative aspects related to adherence. The results showed that adolescents have difficulties in medication adherence especially due to their side effects; they try to normalize their lives in such a way that stigma and discrimination do not compromise their quality of life and treatment adherence. Recommendations to encourage treatment adherence are presented.

DESCRIPTORS: HIV; acquired immunodeficiency syndrome; adolescent; antiretroviral therapy, highly active

\section{ADHESIÓN AL TRATAMIENTO: VIVENCIAS DE ADOLESCENTES CON HIV/SIDA}

Vivir con una condición crónica es algo difícil en cualquier fase de la vida, sobre todo cuando se habla de HIV/ SIDA, condición que trae estigma y discriminación, y cuando ocurre en la adolescencia se muestra como un agravante. El objetivo de este estudio es comprender la experiencia de adolescentes portadores de HIV/SIDA, en lo que se refiere a la adhesión medicamentosa. Se trata de estudio descriptivo, con abordaje cualitativo de los datos. Participaron nueve adolescentes con edad entre 12 y 18 años y seis cuidadores. Los datos fueron organizados alrededor de las facilidades y dificultades relacionadas a la adhesión. Los resultados evidenciaron que los adolescentes tienen dificultades en la adhesión al medicamento, colocando esas dificultades principalmente en los efectos colaterales de los mismos; buscan vivir el proceso de normalización, de tal forma que el estigma y discriminación no comprometan su calidad de vida y la adhesión a la terapéutica. Son presentadas recomendaciones para estimular la adhesión al tratamiento.

DESCRIPTORES: VIH; síndrome de inmunodeficiencia adquirida; adolescente; terapia antirretroviral altamente activa

\section{ADESÃO AO TRATAMENTO: VIVÊNCIAS DE ADOLESCENTES COM HIV/AIDS}

Viver com uma condição crônica é algo difícil em qualquer fase da vida, ainda mais quando se fala de HIV/ AIDS, condição que traz estigma e discriminação, e quando ocorre na adolescência mostra-se como agravante. O objetivo deste estudo é compreender a experiência de adolescentes portadores de HIV/AIDS, no que diz respeito à adesão medicamentosa. Trata-se de estudo descritivo, com abordagem qualitativa dos dados. Participaram nove adolescentes com idade entre 12 e 18 anos e seis cuidadores. Os dados foram organizados ao redor das facilidades e dificuldades relacionadas à adesão. Os resultados evidenciaram que os adolescentes têm dificuldades na adesão ao medicamento, colocando tais dificuldades principalmente nos efeitos colaterais dos mesmos; procuram viver o processo de normalização, de tal forma que o estigma e discriminação não comprometam a sua qualidade de vida e a adesão à terapêutica. São apresentadas recomendações para estimular a adesão ao tratamento.

DESCRITORES: HIV; síndrome de imunodeficiência adquirida; adolescente; terapia anti-retroviral de alta atividade

${ }^{1}$ RN, M.Sc. in Nursing, Hospital das Clínicas, Faculdade de Medicina de Ribeirão Preto, Universidade de São Paulo, Brazil, e-mail: mfck@yahoo.com. ${ }^{2}$ RN, Ph.D. in Nursing, Full Professor, Escola de Enfermagem de Ribeirão Preto, Universidade de São Paulo, WHO Collaborating Centre for Nursing Research Development, Brazil, e-mail: limare@eerp.usp.br. 


\section{INTRODUCTION}

Adolescence is a stage in the growth and development process, the key marks of which are physical and psycho-emotional changes, which are interconnected with culture, social relationships, religion and gender issues ${ }^{(1)}$. It is seen as a phase of turbulence, discoveries, decision-making and internal conflicts in search of identity and maturity, which tend to aggravate when a disease with chronic characteristics is associated with it.

It is difficult for adolescents to accept the disease, because in addition to changes and conflicts inherent to the age itself, having a chronic condition intensifies such conflicts that reflect on their social environment, daily activities, sexuality and relationships with other people, generating physical and psychological limitations ${ }^{(2)}$. These limitations are aggravated when the disease is incurable, infectious and transmitted by the mother, which, in the case of AIDS, is routinely stigmatized and treated with discrimination and prejudice.

The number of adolescents (13 to 19 years old) with AIDS reported to the Brazilian Health Ministry up to 2007 was 10,337. 5,384 were female and 4,953 were male; only 180 of them acquired the disease through vertical transmission ${ }^{(3)}$. There are no records of those already in adulthood who may have been infected through vertical transmission.

Adolescents with HIV/AIDS experience challenges related to the disease such as a complex therapeutic regime, periodic medical visits, a large number of medications with unpleasant flavors and side effects in addition to hospitalization in the case of intercurrences. Yet, many of them do not understand such measures since the diagnosis is not disclosed to them $^{(4)}$.

The chronicity of this disease implies treatment adherence because it is the only thing that controls the disease, suppressing viral replication and consequently improving quality of life. A literature review $^{(5)}$ identified a large variation in the rates of adherence to the antiretroviral therapy among American children and adolescents with indices of 50 to $75 \%$, which are considered inadequate.

Another study addressing adherence of HIV soropositive American adolescents with ages ranging between 12 and 19 years, who were infected through sexual intercourse or drugs, identified the following reasons for not adhering to treatment: forgetfulness, changes in daily routine, excessive number of pills and the side effects caused by antiretroviral drugs. The fact that the medication reminds patients of their HIV, having to take the medicine for a long period of time, even for life, the absence of physical symptoms and depression ${ }^{(6)}$, were other factors reported as causes of non-adherence.

This study aimed to understand the experience of adolescents who acquired HIV/AIDS through vertical transmission in relation to medication adherence. The relevance of this study is justified by the need to identify aspects that simplify medication adherence so that such aspects are included in models of health intervention directing integral and interdisciplinary care delivery in HIV/AIDS.

\section{METHODOLOGICAL APPROACH}

This is a descriptive-exploratory study with qualitative analysis of data due to the nature of the object of study and the proposed objective.

The study was carried out in a unit specializing in infectious diseases in a school hospital in the interior of São Paulo, Brazil. Nine adolescents aged between 12 and 18 years diagnosed with HIV/AIDS since childhood and under antiretroviral therapy were selected with their respective caregivers, among them, mothers, grandmothers, grandfathers and aunt. This number was determined during the data collection process and not before hand, since it provided support to the understanding of the studied phenomenon.

The adolescents were selected during the support group meetings held weekly. Only six of the caregivers participated in the study because two of them did not agree to participate and one of the adolescents asked that her caregiver not be interviewed. Data were collected through semistructured interviews with adolescents, which consisted of two parts, the first of identification data (name, age, gender, education and professional occupation) and the second part was composed of guiding questions that focused on the disease experience, treatment aspects, particularly those related to medication therapy, daily routine and aid family members provide in care management. Information on patients' files about therapeutic protocol, viral load and CD4+ complemented data.

An open interview was carried out with the caregivers with an initial question asking them to tell 
about the adolescents' life from birth until the present day, focusing on aspects related to the antiretroviral therapy.

All interviews were recorded after the participants' authorization and all adolescents and caregivers opted to give the interview in the health service facility.

Data analysis followed all stages recommended by the content analysis technique, that is, pre-analysis, analysis of expressed and latent meanings, elaboration of themes and final analysis ${ }^{(7)}$.

According to the $\operatorname{law}^{(8)}$ that regulates research with human subjects, the project was submitted to and approved by the Research Ethics Committee at the institution where the study was carried out. As part of the paperwork, a free and informed consent agreement was developed in simple language, so that adolescents under retroviral treatment and their caregivers were informed about the study's objectives, procedures, risks, inconveniences and benefits. They were ensured of their anonymity and right not to participate. After the agreement was discussed, all those who agreed to participate signed the document to confirm their consent. The names of the participants are fictitious and caregivers are also identified by kinship.

\section{RESULTS AND DISCUSSION}

As already mentioned, our aim was to understand the experiences of adolescents with HIV/ AIDS based on their narratives and those of their caregivers.

The adolescents participating in this study reported feeling as normal as their peers.

It's normal to live with HIV. It's like a person who has no problem at all; I live just like my sisters (Elisa, 15 years) old

Living with HIV is normal. It's the same of having nothing, 'cause I can go out, play, nobody discriminates, nobody says anything (Daniel, 13 years old).

This perception was justified because they were able to perform daily tasks such as playing, playing ball and going to school, that is, they have a normal life like any other adolescent, like their siblings and friends. They also compared their life with that of other adolescents with other kind of chronic conditions, which, according to their perspectives and those of their family members can be even worse because those other conditions may require more restrictive therapeutic regimes.

We already said to her that if she thinks it is bad, there are other kinds of diseases that are even worse. People with diabetes have, in addition to the medication, to balance their food, they can't eat everything. Aren't there adolescents with diabetes who like to eat chocolate but can't? Isn't it difficult as well? She has to start to understand that in the same way it's difficult to us adults, it's not easy to be obligated to do something, nobody likes to be required to do something, to have to take medication (Ms. Camila, Carolina's mother).

Comparison with other chronic conditions can be explained by the fact they want to believe that living with HIV/AIDS is not so abnormal as it seems and, in this way, they try to accept the disease. However, this feeling of normality can be lost when they experience stigma and discrimination due to the disease.

Adolescents with HIV/AIDS can perceive themselves different due to the required special care such as frequent medical follow-up, medication, limitation of movement in addition to the physical appearance. Nonetheless they do not want to be seen as people with health problems, carrying the stigma of ill people; they desire to be seen as normal people ${ }^{(9)}$.

The perception of normality can influence medication adherence if they do not feel sick. The absence of symptoms can interfere with the perception of the severity of the disease and, consequently, become a factor for non-adherence ${ }^{(10)}$.

Adolescents report situations when stigma and discrimination are evidenced in their daily lives and therefore opt to hide their serological status.

When boys want to offend someone at school, they call them 'aidetic' [derogating term for people with AIDS] or when someone is too thin, are also called 'aidetic', they say: gross, don't get any closer. Things like these are bad. (Beatriz, 18 years old).

My mother is annoying. Sometimes, I go to see some job and she says I'll never get it because I have spots in my skin, because I'm too sick, so I stop looking for a job. I get sad and then stop taking medication. She also says that I cannot find a boyfriend, that whoever I find has to have HIV also, otherwise I'll get anyone on the streets and then I won't know what people have (Beatriz, 18 years old).

We observed in the reports that discrimination and prejudice can sometimes originate within the family itself, which is supposed to help and provide emotional support to adolescents. 
One grandmother believes her granddaughter stopped taking medication because she suffered discrimination from her brother and also because she believed that her friends at school knew her diagnosis.

My granddaughter took the medication up to one year and half ago, she didn't give anyone a hard time up to that point, took it everyday. After that she started to give me a hard time, wouldn't take it, would put up a fight. I guess she started to revolt because of school, somebody must have mentioned it because of her brother, because when he fought with her, he'd $n$ scream for everyone to listen (Ms. Isadora, Isabela's grandmother).

This same discriminatory and stigmatizing feeling was pointed out in another study with adolescents with HIV/AIDS and their caregivers ${ }^{(11)}$. Discrimination can lead people to isolate themselves and might become another factor hindering medication adherence $^{(12)}$.

Fear of prejudice and discrimination tend to lead people with HIV/AIDS to postpone disclosing their diagnosis, and this decision affects access to health care and sexual, affective, social and educational life $e^{(13)}$.

We also perceive that from the moment in which adolescents experience prejudice and discrimination, they start to seek someone to blame, since they had no intention to acquire HIV.

I know how I got it, which was sometime during delivery. I got it from my mother. I don't blame anyone, but it wasn't my fault either. It's complicated if you have to get treated for something that is nobody's fault. It's frustrating. I guess that with my father is the same thing as with my mother, because she got it from him and saying it to him would be like asking for death. Even now he blames himself for that. Talking to him about it is the same of asking him to die (Carolina, 15 years old).

It's common among adolescents who acquired HIV through vertical transmission to stop taking medication regardless of how much they know about the importance of the treatment and consequences of abandoning it. However, they feel the need to divorce themselves from the treatment and consequently from the disease, so that they feel they are in control of their lives.

Parents frequently report that adolescents are already mature enough to understand the importance and need of the medication ${ }^{(14)}$. However, given that the antiretroviral medication is acknowledged as essential to maintain life ${ }^{(15)}$, the mothers take on themselves the co-responsibility of managing the medication therapy.
Another situation observed in the adolescents' reports is that since AIDS has no cure, they do not need to take medication.

I won't stay with this disease anymore, so I die and will have no more problems (Beatriz, 18 years old).

I'm too lazy to take the medication. If I'm gonna die, let me die. My mom bothers me all the time so I tell her to let it be, leave me alone (Adriana, 15 years old).

These reports show the difficulty of living with a chronic, incurable disease with a strong association with death and irresponsible behavior, a disease not accepted by society, which stigmatizes, discriminates and judges those with HIV/AIDS. These facts can interfere with medication adherence because adolescents are not always prepared to face these situations and instead say that death can be the faster way to solve their problems.

As already observed, medication adherence is important when one refers to HIV/AIDS, since nonadherence leads not only to individual problems such as increased viral load and viral resistance, decreased number of lymphocytes TCD4+ and consequently increased risk of opportunist infections, but also to problems in the public health sphere due to the risk of dissemination of resistant strains ${ }^{(16)}$.

The study's participants raised facts that make medication adherence difficult such as a rigid schedule, the number of pills, altered daily routines and the medications' undesirable side effects.

It seems that she doesn't want to worry about the medication. I guess she wished not to have to take it anymore, she doesn't want to have to take the medication whenever she goes out, because there're times we go to church and I ask, daughter, aren't you going to take the medication? And she says: no, I won't. But because I insist so much, I say, we might stay late, so I say to her to take the medication. She has to have a cell phone, the cell phone has to have the timer on, so it'll goes off at the time she has to take the medication. So I say that since we found out about the disease my life and her life are timed (Ms. Gisela, Gabriele's mother).

It'd fail sometimes because $I^{\prime} d$ forget to put the medication inside my purse when I'd come here (medical return visit), because it gets to be six o'clock and we aren't at home yet. Now, he doesn't forget anymore (Ms. Fabiana, Fabio's grandmother).

The most difficult thing is to take the medication. Its flavor, pain in the stomach, many pills (Beatriz, 18 years old).

Another reason they report for not adhering to medication is the fact it reminds them of the disease. 
There're times it's frustrating, I have to think that I have to go there again and do the same thing every time. Taking medication to cure something that has no cure and which I'm not the one to blame. It's frustrating (Carolina, 15 years old).

It's bad taking medication because when I take it, I remember my HIV. You can't say we have a normal life, like everybody else's, because we don't (Adriana, 15 years old).

Many times I don't accept the disease, so I don't want to take it. Because I want to forget the disease and not accept it (Carolina, 15 years old).

The memory of HIV, having to take medication for something that has no cure and not accepting the disease are factors that exert a direct influence on medication adherence. The absence of symptoms also makes it difficult to acknowledge the disease and consequently, the treatment.

Although less frequently, adolescents also reported the importance of the medication for maintaining life, its quality and even cure.

It's difficult because if you forget the disease, you're asking to die; if you don't take the medication you're asking to get sick and die soon (Carolina, 15 years old).

What helps me to take the medication is my desire to live. I don't know if many people think like me, but I think like, my mom didn't bring me into life in vain and as she hopes to see me with children someday. I also hope to see myself with children someday (Gabriele, 14 years old).

I take medication to cure the disease (Humberto, 13 years old).

Other factors that favor medication adherence are to believe in its benefit for life and survival, to be aware that not taking medication can aggravate the illness, the desire to live and to have a future. Good counseling can also help adherence through better understanding of the disease and needed medication $^{(17)}$.

Adherence should be seen as a process to overcome difficulties, related to a medication regime, disease, experience of stigma and discrimination and to changes in life style ${ }^{(18)}$.

For the adolescents participating in this study, medication adherence is a way to live and survive HIV, because medication helps avoid disease and consequently death, which in turn would bring suffering to people with whom they live.

I'd say to take the medication correctly because for people with HIV, it's a way to survive, to protect people we like, so those we love won't suffer, won't see us dying, won't see us sick in the hospital (Carolina, 15 years old).
Although some adolescents have used terms such as cure, all of them, even those who do not adhere to treatment, are aware of its importance, though, for the reasons already mentioned, some opt not to take the medication; medication adherence should be seen as life adherence since this is what allows controlling the disease.

\section{FINAL CONSIDERATIONS}

With the introduction of the antiretroviral therapy in 1996, mortality and opportunist infections were reduced and survival of patients with HIV/AIDS increased as well as quality of life. Although the participants attributed to AIDS a chronic character, treatment still represents a big challenge, even while it allows them to be reinserted into social, professional and affective life. This is especially so in terms of adherence since the use of medication in levels below $95 \%$ is not enough to keep viral replication suppressed $^{(17)}$

Living with a chronic condition is difficult in any stage of life, but it is aggravated when coupled with adolescence, a phase of conflicts and searching for identity and autonomy. When the illness is AIDS, an infectious, contagious and incurable disease that still bears the sign of death and standards not accepted by society, this process becomes even more complex. We observe that the participants in this study who try to live with other people of their age still face stigma and discrimination, sometimes within their own family.

In relation to medication adherence, adolescents report they know the benefits of the medication to control the disease and to improve their quality of life, however, many of them do not adhere to the treatment and justify this behavior by the nonacceptance of the disease, the reminder that they have HIV, anxiety or even forgetfulness.

The experiences of these adolescents with HIV/AIDS concerning medication adherence could be understood through their reports. This knowledge can aid the proposition of effective interventions in care delivery, so as to help the treatment and diminish the vulnerability of these adolescents to the disease, such as: 1 . Orienting parents about the need to supervise medication, helping them, when needed, to correctly administer them; 2. Creating support groups with adolescents who do not adhere to the medication, 
trying to understand the motives that lead them not to take the medication correctly and intervene early; 3. Qualifying the nursing team for pre- and postconsultation, reminding these professionals that the waiting room can be a place for exchanging experiences and information and that guidance about the use of medication has to be calmly provided so as to identify potential difficulties and clarify doubts; planning, jointly with the adolescent and caregiver, the best schedule so there are no interferences in their routine; 4. Developing, jointly with adolescents and caregivers, posters using medication labels and specifying the times to take them; 5 . Orienting adolescents and caregivers about the use of timers and/or cell phones so they do not forget the correct time for taking medication; 6. Establishing partnerships with city hall and non-governmental organizations with a view to promote talks and workshops for the community and in schools to orient them not only regarding the forms of HIV transmission, but also aiming to minimize stigma and discrimination; 7 . Orienting parents and people with HIV about their basic human rights, emphasizing that those who are noncompliant with them are liable to prosecution; 8 . Developing a program of supervised administration of medication at home as happens with tuberculosis, which has improved patients' adherence, and thus can be a solution for the case of patients with HIV/AIDS.

\section{REFERENCES}

1. Campos GFVA. Adolescência: de que crise estamos falando? [dissertação]. São Paulo (SP): Núcleo de Psicanálise e Sociedade/ PUC; 2006.

2. Siegel K, Lekas HM. AIDS as chronic illness: psychosocial implications. AIDS 2002; 16(suppl4): S.69-S76.

3. Ministério da Saúde (BR). Boletim Epidemiológico AIDST. Brasília (DF): Ministério da Saúde; 2007.

4. Moreira MCN, Cunha CC. Repensando as práticas e dilemas no cotidiano de atenção à saúde de crianças e jovens vivendo com HIV/AIDS. Divulgação em Saúde para Debate 2003; (29): 73-92.

5. Steele R, Grauer D. Adherence to antiretroviral therapy for pediatric HIV infection: review of the literature and recommendations for research. Clin Child Fam Psychol Rev 2003; 6:17-30.

6. Murphy DVA. Barries to haart adherence among immunodeficiency vírus-infected adolescents. Arch Pediatr Adolesc Med 2003; 157:249-55.

7. Minayo MCS. O desafio do conhecimento: pesquisa qualitativa em saúde. $7^{\circ}$ ed. São Paulo (SP): HUCITEC; 2000. 8. Ministério da Saúde (BR). Diretrizes e normas reguladoras de pesquisas envolvendo seres humanos. Brasília: Ministério da Saúde, 2002.

9. Vieira MA, Lima RAG. Crianças e adolescentes com doença crônica: convivendo com mudanças. Rev Latino-am Enfermagem 2002 julho/agosto; 10(4):552-60.

10. Bolono PF, Gomes RRFM, Guimarães MDC. Adesão à terapêutica anti-retroviral (HIV/aids): fatores associados e medidas de adesão. Epidemiol Serviços Saúde 2007 outubro/ dezembro; 16(4):261-78.

11.Lima AMA, Pedro ENR. Growing up with HIV/AIDS: a study on adolescents with HIV/AIDS and their family caregivers. Rev Latino-am Enfermagem 2008 maio/ junho;16(3): 348-54.

12 Teixeira PR, Paiva V, Simma E. Tá difícil engolir? Experiências de adesão ao tratamento anti-retroviral em São Paulo. São Paulo (SP): NEPAIDS; 2000.

13. Ayres JRMC, Paiva V, França-Junior I, Gravato N, Lacerda $R$, Negra $M D$ et al. Vulnerability, human rights, and comprehensive health care needs of young people living with HIV/AIDS. Am J Public Health 2006; 96(6):1001-6.

14. Ledlie SW. The psychosocial issues of children with perinatally adquired HIV disease becoming adolescents: a growing challenge for providers. AIDS Patient Care and STDs 2001; (15):231-6.

15. Silva RAR, Rocha VM, Davim RMB, Torres GV. Ways of coping with AIDS: opinion of mothers with HIV children. Rev Latino-am Enfermagem 2008 março/abril; 16(2):260-5.

16. Merzel C, VanDevnater N, Irvine M. Adherence to antiretroviral therapy among older children and adolescents with HIV: a qualitative study of psychosocial contexts. AIDS Patient Care and STDs 2008; 22(12):977-87.

17. Remien RH, Hirky AE, Johnson MO, Weinhardt LS, Whittier $D$, Le GM. Adherence to medication treatment: a qualitive study of facilitators and barriers among a diverse sample of HIV + men and women in four U.S. cities. AIDS Behav 2003; $1(7): 61-72$.

18. Guimarães MS, Raxach JC. A questão da adesão: os desafios impostos pela aids no Brasil e as respostas do governo, de pessoas e da sociedade. Impulso 2002; (32):69-89.

19. Gianna MC, Kalichman A, Teixeira PR. Apresentação. In: Caraciolo JM, Shimma E. Adesão: da teoria a prática. Experiências bem sucedidas no Estado de São Paulo. São Paulo (SP): CRT DST/AIDS; 2007. p. 5-7. 